\title{
WORLD ASSOCIATION FOR THE ADVANCEMENT OF VETERINARY PARASITOLOGY
}

The Association will hold its Seventh International Conference at Thessaloniki, Greece on 14-16 July, 1975, immediately after the XX World Veterinary Congress.

The theme of the Conference is on Pathophysiology of Parasitic Infections but there will also be a General Session on Advances in Parasitology.

Titles and abstracts of papers should be submitted before April 1, 1975, to the Chairman of the Programme Committee:-

Professor E. J. L. Soulsby

Department of Pathobiology, School of Veterinary Medicine

University of Pennsylvania

3000 Spruce Street

Philadelphia, Pennsylvania 19104, U.S.A.

Preregistration and any inquiries about organization and social programme should be sent to the local Chairman:-

Professor C. A. Himonas

Head of the Department of Applied Helminthology and Entomology

Faculty of Veterinary Medicine

Aristotelian University, Thessaloniki, Greece. 


\section{INSTRUCTIONS TO CONTRIBUTORS}

The Journal of Helminthology publishes papers on all aspects of animal parasitic helminths, particularly those of medical or veterinary importance.

Manuscripts, which must be in English or French (with an English summary), should be addressed to:

The Editor, Journal of Helminthology,

London School of Hygiene and Tropical Medicine,

Keppel Street, London, WCIE 7HT.

England.

Two copies of a typescript, on size A4 paper with double spacing, should be submitted. Papers should be preceded by a short abstract and will normally have the following sections: brief introduction (unheaded); Materials and Methods; Results; Discussion; Acknowledgements; References. However, the form of the paper may vary, depending on its subject matter; recent past issues should be consulted for a suitable form. Illustrations should be drawn in Indian ink, preferably not more than double the final size. Care should be taken that all illustrations fit into the format of the Journal. The maximum size an illustration may be printed is $13.5 \times 18 \mathrm{~cm}$. Where many separate drawings are made, some indication of how they may be grouped to make a corporate plate without undue wastage of space, should be indicated. Some indication of scale should normally be given on the figure. Photocopies of illustrations should also be enclosed for refereeing purposes. Lettering and numbering, which must be of a high standard, should be added by "the author, with due regard for subsequent reduction.

Photographs should be glossy prints of the same size as they are to appear in the Journal (maximum size $13.5 \times 18 \mathrm{~cm}$ ). Composite prints must be mounted and can have the separate photographs abutting; they will then have a separating line inserted by the printers. All figures and letters on photographs must be inserted by the author.

Information should not be repeated in the text and in tables or figures. The legends to tables and to figures should be sufficiently detailed for the information to be understood without reference to the text.

References should be given in alphabetical order with the full title of the journal. The following are examples:

DUKE, B. O. L. (1971) The ecology of onchocerciasis in man and animals. In Ecology and physiology of parasites (ed A. M. Fallis) pp. 213-222. Adam Hilger Ltd.: London.

JAMES, C. and WEBBE. G. (1973) A comparison of Egyptian and East African strains of Schistosoma haematobium. Journal of Helminthology, 47, 49-59.

50 offprints are provided free of charge; additional copies may be ordered at the proof stage. 


\section{Contents}

McGREEVY, P. B., THEIS, J. H., LAVOIPIERRE, M. M. J. and CLARK, J. Studies on filariasis. III. Dirofilaria immitis: emergence of infective larvae from the mouthparts of Aedes aegypti

SMITH, J. W. Experimental transfer of Anisakis sp. larvae (Nematoda: Ascaridida) from one fish host to another

READER, T. A. J. Autoradiographic studies on the uptake of $\left[{ }^{14} \mathrm{C}\right]$-Glucose by Bithynia tentaculata (Mollusca : Gastropoda) and its larval digeneans

SADIGHIAN, A., GHADIRIAN, E. and SADJAPOUR, E. Two new species of nematodes of lagomorphs and rodents from Iran

TINSLEY, R. C. and SWEETING, R. A. Studies on the biology and taxonomy of Diplostomulum (Ty/ode/phylus) xenopodis from the African clawed toad, Xenopus laevis

DENHAM, D. A. Studies with Brugia pahangi 8. Infections in Macaca mulatta

WOOTTEN, R. Studies on the life history and development of Proteocephalus percae (Müller) (Cestoda: Proteocephalidea)

MELLOR, P. S. Studies on Onchocerca cervicalis Railliet and Henry, 1910: IV. Behaviour of the vector Culicoides nubeculosus in relation to the transmission of Onchocerca cervicalis

CHAUHAN, P. P. S., ARORA, G. S. and AHLUWALIA, S. S. A note on the occurrence of an immature parafilariid worm in the anterior chamber of eye of a buffalo (Bubalus bubalis)

OW YANG, C. K. On the life history of Hepatojarakus malayae (Nematoda: Trichostrongylidae), a parasite of the feral rat in Malaysia 